Jurnal Keperawatan Silampari

Volume 5, Nomor 1, Desember 2021

e-ISSN: 2581-1975

p-ISSN: 2597-7482

DOI: https://doi.org/10.31539/jks.v5i1.2905

\title{
FAKTOR-FAKTOR YANG BERHUBUNGAN DENGAN IMT DAN KADAR GULA DARAH PERAWAT PROFESIONAL
}

\author{
Ernawati Siagian $^{1}$, Samuel Maju Simanjuntak ${ }^{2}$ \\ Universitas Advent Indonesia ${ }^{1,2}$ \\ ernawatisiagian@unai.edu ${ }^{1}$
}

\begin{abstract}
ABSTRAK
Penelitian ini bertujuan untuk mengetahui gambaran variabel atribut, pola aktivitas harian, IMT dan kadar gula darah pada perawat. Serta mencari tahu apakah terdapat hubungan antara variable atribut, pola aktivitas terhadap IMT dan kadar gula darah para perawat. Metode yang digunakan dalam penelitian ini adalah descriptive correlational. Hasil IMT menunjukan bahwa obese I (58\%). Obese II (42\%), hasil kadar gula darah puasa Prediabetes (28\%), diabetes (4\%). Sedangkan hasil pola aktifitas fisik sedang ada $80 \%$ METs-menit/minggu. Analisis menggunakan rumus korelasi yaitu Pearson $r$ dan Spearman rho menunjukkan bahwa ada hubungan yang signifikan antara usia dan pola aktifitas fisik (METs-menit/minggu) dengan p-value 0,022. Adanya hubungan yang signifikan antara status pernikahan (marital) dengan pola aktifitas fisik dengan p-value 0,005. Simpulan, perawat sebagai salah satu sumber daya yang berperan penting dalam pelayanan kesehatan dan memiliki peran yang esensial, pertama yaitu untuk melakukan promosi kesehatan dan pencegahan primer.
\end{abstract}

Kata Kunci: Gula Darah, IMT, Obesitas, Perawat, Pola Aktivitas

\begin{abstract}
This study aims to determine attribute variables, daily activity patterns, BMI, and blood sugar levels in nurses. And find out whether there is a relationship between attribute variables, activity patterns on BMI, and blood sugar levels of nurses. The method used in this study is descriptive correlational BMI results show that obese I (58\%). Obese II (42\%), fasting blood sugar results Prediabetes (28\%), diabetes (4\%). At the same time, the results of moderate physical activity patterns were $80 \%$ METs-minutes/week. Analysis using the correlation formula, namely Pearson $r$ and Spearman rho, showed a significant relationship between age and physical activity patterns (METs-minutes/week) with a pvalue of 0.022. There is a meaningful relationship between marital status and physical activity patterns with a p-value of 0.005. In conclusion, nurses as one of the resources that play an essential role in health services and have an indispensable part, first, namely to carry out health promotion and primary prevention.
\end{abstract}

Keywords: Blood Sugar, BMI, Obesity, Nurse, Activity Pattern 


\section{PENDAHULUAN}

Kegemukan dan obesitas merupakan akumulasi kelebihan jaringan adiposa yang terkait dengan gangguan kesehatan dan kesejahteraan fisik serta psikososial (World Health Organization, 2021). Obesitas dikaitkan dengan peningkatan risiko berbagai kondisi kesehatan termasuk diabetes, kanker, penyakit jantung, gangguan muskuloskeletal, dan kesehatan psikologis yang buruk (World Health Organization, 2021). Lebih dari 1,9 miliar dan 650 juta orang dewasa di seluruh dunia berusia 18 tahun dan yang lebih tua masingmasing kelebihan berat badan dan obesitas, dan jumlah kematian yang dikaitkan dengan kelebihan berat badan dan obesitas lebih besar daripada yang terkait dengan kekurangan berat badan (World Health Organization, 2021).

Sebanyak 69\% perawat terdaftar di Inggris (UK) kelebihan berat badan atau obesitas (Kyle et al., 2017). Sebuah penelitian di Skotlandia menemukan bahwa 29\% perawat, 17\% profesional kesehatan lainnya (termasuk dokter, apoteker, dokter gigi, dan profesional terapi) dan 35\% pekerja perawatan yang tidak terdaftar mengalami obesitas (Kyle et al., 2016). Penting untuk dapat memiliki penilaian yang akurat tentang prevalensi obesitas di kalangan profesional kesehatan karena tiga alasan utama. Pertama, obesitas meningkatkan kemungkinan gangguan muskuloskeletal dan kondisi kesehatan mental, yang merupakan penyebab utama penyakit terkait pekerjaan dan cedera di tempat kerja bagi profesional kesehatan. Selain terlibat dalam timbulnya penyakit kronis, kondisi ini dan dampaknya tingkat ketidakhadiran penyakit terkait menimbulkan masalah potensial untuk keberhasilan dan keberlanjutan sistem perawatan kesehatan dengan berpotensi mengurangi kapasitas tenaga kerja perawatan kesehatan (Health and Safety Executive, 2017).

Indeks Massa Tubuh (IMT) adalah metode sederhana yang digunakan untuk menilai status gizi seorang individu, namun tidak dapat mengukur lemak tubuh secara langsung. IMT dikatakan sebagai faktor resiko utama berkembangnya resistensi insulin pada penderita diabetes mellitus tipe 2 . Sekitar $70 \%$ penderita diabetes adalah overweight dan lebih dari $50 \%$ pasien dengan obesitas mengalami penurunan toleransi glukosa. Obesitas dapat menyebabkan inflamasi sistemik dan lokal tingkat rendah kronis yang mengarah pada munculnya resistensi insulin terkait diabetes mellitus. Selain itu, resistensi insulin dan hiperinsulinemia dapat berkontribusi pada perkembangan obesitas (Wondmkun, 2020). Berdasarkan hasil Riskesdas Tahun 2018 rata-rata prevalensi diabetes di Indonesia sebesar 1.017.290 juta jiwa. Jawa Timur menduduki peringkat keempat terbesar setelah DKI Jakarta, Yogyakarta, Kalimantan Timur dan Sulawesi Utara dengan prevalensi sebesar 151.878 ribu jiwa. Hasil tersebut menunjukkan bahwa prevalensi diabetes di Jawa Timur masih tergolong tinggi dibandingkan dengan rata-rata prevalensi diabetes di Indonesia. Klasifikasi berat badan sehat didasarkan pada indeks masa tubuh (BMI). BMI yang sehat dianggap 18,50 hingga 24,99 persen. Seseorang dianggap kelebihan berat badan ketika BMI-nya 25,00 hingga 29,99 persen dan BMI lebih dari 30 persen dianggap obesitas.

Penelitian yang mengukur obesitas menggunakan evaluasi indeks massa tubuh menunjukkan beberapa faktor yang berkontribusi terhadap obesitas pada perawat adalah: diet yang tidak tepat, tidak ada aktivitas fisik, tidak ada waktu tidur rutin dan stress yang tinggi. Penjadwalan shift yang tepat, pelatihan manajemen waktu, dan akses ke pilihan makan siang yang sehat dan dorongan untuk menerapkan gaya hidup sehat dapat mengubah indeks obesitas di kalangan perawat. Memiliki pekerjaan stres tinggi dan banyak tanggung jawab yang membuat perawat mengembangkan kebiasaan makan yang buruk dan kurang tidur. Faktanya, kerja shift dapat membuat ketidaksinkronan pekerja secara umum ritme kehidupan dan mengubah ritme fisiologistubuh. Pergeseran dan belokan memiliki dampak yang kuat pada semua aspek kehidupan pekerja, termasuk perubahan kebiasaan makan, 
perubahan fisik, aktivitas, ritme sirkadian, serta berbagai jenis lainnya dari perilaku (Saulle et al., 2018).

Pola makan merupakan suatu cara dalam pengaturan jumlah dan jenis makanan dengan maksud mempertahankan kesehatan, status nutrisi, mencegah atau membantu kesembuhan penyakit. Penelitian telah menunjukkan pentingnya kualitas diet dengan hasil kesehatan, dan diet sehat secara konsisten terbukti dikaitkan dengan risiko obesitas, diabetes tipe 2, dan CVD yang lebih rendah. Aktifitas olahraga memiliki peranan sangat penting bagi pengendalian kadar glukosa darah, mampu membakar kalori dan mengurangi lemak tubuh sehingga dapat meningkatkan kemampuan metabolisme sel dalam menyerap dan menyimpan glukosa, semakin banyak kalori yang terbakar oleh aktifitas olahraga bisa menurunkan kadar glukosa yang tinggi. Menurut WHO (2018) latihan olahraga dan aktivitas fisik telah dianggap sebagai landasan dalam pencegahan dan pengobatan DMT2. Seiring dengan kontrol glikemik, olahraga memiliki sejumlah manfaat, seperti menurunkan IR dan meningkatkan kapasitas aerobik, kekuatan otot, komposisi tubuh, dan fungsi endotel (Kumar et al., 2018).

Rumah sakit yang menjadi lokasi penelitian ini merupakan salah satu rumah sakit swasta di Bandar Lampung. Pada pertengahan tahun 2019 pihak manajemen Rumah Sakit mengadakan Medical Check Up kepada tenaga professional, dan di peroleh data ada sekitar $57,9 \%$ dari 269 orang yang mengalami kelebihan berat badan dan obesitas. Sedangkan yang mengalami peningkatan kadar gula darah di atas normal sekitar $29 \%$ atau 25 orang. Jumlah perawat professional di rumah sakit ini ada 207 perawat dan ada 53,1\% mengalami kelebihan berat badan dan obesitas. Tujuan dari penelitian ini adalah mengetahui gambaran variable atribut, pola aktivitas harian, IMT dan kadar gula darah pada perawat profesional. Serta mencari tahu apakah terdapat hubungan antara variable atribut, pola aktivitas terhadap IMT dan kadar gula darah para perawat profesional. Penelitian ini juga bermanfaat menambah pengetahuan perawat sebagai sumber untuk memahami dan melakukan aktivitas fisik, serta mempertahankan berat badan yang sehat. Dengan begitu, diharapkan dapat mempengaruhi kesejahteraan perawat di tempat kerja dan keselamatan pasien. Selain itu, penelitian ini belum pernah dilakukan ditempat penelitian.

\section{METODE PENELITIAN}

Pada penelitian ini menggunakan design description correlational yang dilakukan kepada 50 orang perawat. Pengambilan sampel dilakukan menggunakan teknik purposive sampling. Populasi responden adalah perawat perempuan dewasa yang bekerja di Rumah Sakit Advent Bandar Lampung. Penelitian dilaksanakan setelah mendapatkan persetujuan dari Komite Etik Penelitian Kesehatan Research Ethics Committee Universitas Advent Indonesia No. 087/KEPK-FIK.UNAI/EC/VII/20dan Surat ijin penelitian dari Direktur Rumah Sakit Advent Bandar Lampung No. 227/RSA-BL/VII/2020.Analisa univariat dilakukan untuk menentukan frekuensi dan persentase dari masing-masing vairabel.

Analisa bivariate dilakukan dengan menggunakan rumus korelasi yaitu Pearson $r$ dan Spearman rho. Pengumpulan data yang dilakukan adalah mengukur berat badan, tinggi badan untuk mendapatkan hasil IMT. Informasi aktifitas fisik responden diukur dengan metode wawancara terstruktur menggunakan panduan International Physical Activity Questionnaire versi Short-Form (IPAQ-SF) yang telah diterjemahkan ke dalam Bahasa Indonesia. Panduan International Physical Activity Questionnaire versi Short-Form (IPAQSF) Kuesioner terdiri dari 7 pertanyaan berdasarkan aktivitas fisik yang dilakukan oleh responden selama 7 hari terakhir. 
Hasil wawancara selanjutnya diolah menggunakan panduan IPAQ scoring protocol dengan bantuan IPAQ automatic report sehingga diperoleh data aktifitas fisik. IPAQ menggunakan MET (Metabolic Equivalent of Task) sebagai satuan. Untuk mendapatkan nilai kadar gula darah, meminta responden untuk berpuasa selama 10 jam dimulai dari malam hari, dimana keesokan paginya dilakukan pengambilan darah dengan alat pengukur gula darah (Accu Check).

\section{HASIL PENELITIAN}

Tabel. 1

Distribusi Karakteristik Responden ( $\mathrm{N}=50)$

\begin{tabular}{cccc}
\hline Variabel & Kategori & Frekuensi & Persentase \\
\hline Usia & $21-30$ tahun & 5 & $10 \%$ \\
& $31-40$ tahun & 23 & $46 \%$ \\
& $41-50$ tahun & 19 & $38 \%$ \\
& 51 tahun & 3 & $6 \%$ \\
\hline Marital & Belummenikah & 7 & $14 \%$ \\
& Menikah & 43 & $86 \%$ \\
\hline Kontrasepsi & Tidak & 13 & $26 \%$ \\
& Steril & 19 & $38 \%$ \\
& Spiral & 8 & $16 \%$ \\
& Kalender & 10 & $20 \%$ \\
\hline Penyakit kronis & Tidak & 42 & $84 \%$ \\
& Memiliki & 8 & $16 \%$ \\
\hline Penyakit keluarga & Tidak & 29 & $58 \%$ \\
& Hipertensi & 17 & $34 \%$ \\
& DM & 4 & $8 \%$ \\
\hline Perawat Klinis & PK I & 8 & $16 \%$ \\
& PK II & 8 & $16 \%$ \\
& PK III & 34 & $68 \%$ \\
\hline Departemen & OPD & 2 & $4 \%$ \\
& ICU & 2 & $4 \%$ \\
& OB & 7 & $14 \%$ \\
& Med-Surg & 39 & $78 \%$ \\
\hline Jadwal Kerja & Nite Shift & 48 & $96 \%$ \\
& AM Shift & 2 & $4 \%$ \\
\hline & & &
\end{tabular}

Berdasarkan tabel 1 menunjukan bahwa sebagian besar responden adalah berusia 3140 tahun (46\%), status pernikahan yang menikah (86\%), kontrasepsi yang steril (38\%), penyakit kronis (16\%) dan riwayat penyakit keluarga hipertensi (34\%) dan DM (8\%), posisi PK III (68\%), tempat bekerkja di bagian medical surgical 39 orang (78\%) dan yang bekerja nite shift ada 48 orang (96\%).

Tabel . 2

Aktivitas Setelah Bekerja

\begin{tabular}{ccc}
\hline Intensitas Aktivitas & Frekuensi & Persentase \\
\hline Mencuci & 29 & $58 \%$ \\
Menggosok & 42 & $84 \%$ \\
Memasak & 43 & $86 \%$ \\
Mengajar Anak & 27 & $54 \%$ \\
Berbelanja & 42 & $84 \%$ \\
Membersihkan Rumah & 42 & $84 \%$ \\
\hline
\end{tabular}


Berdasrkan tabel 2 menunjukkan bahwa mayoritas aktivitas setelah bekerja adalah memasak yaitu sebanyak 43 responden $(86 \%)$.

Tabel. 3

Persentase IMT, Gula darah Puasa, METs

\begin{tabular}{cccc}
\hline Variabel & Kategori & Frekuensi & Persentase \\
\hline IMT & & & \\
$<18,5$ & Kurang & 0 & $0 \%$ \\
$18,5-22,9$ & Normal & 0 & $0 \%$ \\
$23-24,9$ & Overweight & 0 & $0 \%$ \\
$25-29,9$ & Obese I & 29 & $58 \%$ \\
$>30$ & Obese II & 21 & $42 \%$ \\
\hline Gula darah puasa & Kategori & Frekuensi & Persentase \\
$<100$ & Normal & 34 & $68 \%$ \\
$101-125$ & Pre Diabetes & 14 & $28 \%$ \\
$>125$ & Diabetes & 2 & $4 \%$ \\
METs & & & $8 \%$ \\
$<600$ & Ringan & 4 & $80 \%$ \\
$600-1500$ & Sedang & 40 & $12 \%$ \\
$>1500$ & Tinggi & 6 & \\
\hline
\end{tabular}

Berdasarkan tabel 3 menunjukan bahwa obese I (58\%) dan (42\%) obese II, mayoritas responden menunjukkan prediabetes $(28 \%)$ dan yang memiliki nilai METs pada aktifitas fisik sedang (80\%).

Tabel. 4

Usia dan Pola Aktivitas

\begin{tabular}{cccccc}
\hline \multirow{2}{*}{$\begin{array}{c}\text { Spearman } \\
\text { rho }\end{array}$} & Variabel & Mean & Standar Deviasi & Sig & $\begin{array}{c}\text { Correlation } \\
\text { Coeficient }\end{array}$ \\
\cline { 2 - 6 } & Usia & 2.40 & .756 & 0.22 & .323 \\
\hline
\end{tabular}

Berdasarkan tabel 4 menunjukan bahwa ada hubungan yang signifikan antara usia dan pola aktivitas dengan nilai sig 0,022 . Nilai correlation coefficient 0,323 menunjukkan tanda positif yang berarti bahwa usia dan pola aktifitas memiliki hubungan yang searah dengan tingkat keeratan hubungan yang cukup.

Tabel.5

Marital dan Pola Aktivitas

\begin{tabular}{lccccc}
\hline \multirow{3}{*}{$\begin{array}{l}\text { Spearman } \\
\text { rho }\end{array}$} & Variabel & Mean & StandarDeviasi & Sig & Correlation Coeficient \\
\cline { 2 - 6 } & Marital & 1.86 & 351 & 0.05 & .391 \\
\hline
\end{tabular}

Berdasarkan tabel 5 menunjukan bahwa ada hubungan yang signifikan antara maritaldan pola aktivitasdengan nilai sig 0,005 . Nilai correlation coefficient 0,391 menunjukkan tanda positif yang berarti bahwa usia dan pola aktifitas memiliki hubungan yang searah dengan tingkat keeratan hubungan yang cukup. 
Tabel. 6

IMT dan Gula Darah

\begin{tabular}{lccccc}
\hline & Variabel & Mean & Standar Deviasi & Sig & Correlation Coeficient \\
\cline { 2 - 6 } Spearman & IMT & 29.3788 & 3.08695 & 0.906 & .017 \\
Rho & Gula Darah & 95.70 & 14.857 & & \\
\hline
\end{tabular}

Berdasarkan tabel 6 menunjukan bahwa tidak ada hubungan yang signifikan antara IMTdan Gula darah dengan nilai sig 0,906. Nilai correlation coefficient 0,906 menunjukkan tanda negatif yang berarti bahwa IMT dan Gula darah memiliki hubungan yang berlawanan dengan tingkat keeratan hubungan yang sangat lemah.

Tabel. 7

Hubungan Masing-Masing Variabel dengan IMT dan Gula Darah

\begin{tabular}{cccccc}
\hline & Variabel & \multicolumn{2}{c}{ IMT } & \multicolumn{2}{c}{ Gula Darah } \\
\cline { 2 - 6 } & & $\begin{array}{c}\text { Correlation } \\
\text { Coefficient }\end{array}$ & $\begin{array}{c}\text { Sig (2- } \\
\text { tailed) }\end{array}$ & $\begin{array}{c}\text { Correlation } \\
\text { Coefficient }\end{array}$ & $\begin{array}{c}\text { Sig (2- } \\
\text { tailed) }\end{array}$ \\
\cline { 2 - 6 } Spearman & & .000 & 0,998 & .149 & 0,300 \\
Rho & Usia & .110 & 0,448 & .218 & 0,128 \\
& Marital & .062 & 0,668 & .029 & 0,843 \\
& Kontrasepsi & .255 & 0,074 & .220 & 0,125 \\
& Penyakit Kronis & .215 & 0,133 & .132 & 0,360 \\
\hline
\end{tabular}

Berdasarkan tabel 7 menunjukkan bahwa usia, status marital, kontrasepsi, penyakit kronis dan penyakit keluarga tidak ada hubungan yang signifikan dengan IMT dan Gula darah (sig> 0,05).

Tabel. 8

Hubungan Masing-Masing Variabel dengan Pola Aktifitas

\begin{tabular}{lccc}
\hline & Variabel & \multicolumn{2}{c}{ METs } \\
\cline { 2 - 4 } & & Correlation & Sig (2- \\
Coefficient & tailed) \\
\cline { 2 - 4 } Spearman Rho & Usia & .323 & 0,022 \\
& Marital & .391 & 0,005 \\
& Kontrasepsi & .212 & 0,139 \\
& Penyakit Kronis & .031 & 0,830 \\
& Penyakit Keluarga & .169 & 0,240 \\
\hline
\end{tabular}

Berdasarkan tabel 8 menunjukan bahwa usia, dan status marital, ada hubungan yang signifikan dengan pola aktifitas (sig< 0,05$)$. Sedangkan variabel kontrasepsi, penyakit kronis dan penyakit keluarga tidak ada hubungan yang signifikan dengan pola aktifitas.

Tabel. 9

HubunganPola Aktifitas dengan IMT dan Gula Darah

\begin{tabular}{cccccc}
\hline \multirow{2}{*}{$\begin{array}{c}\text { Spearman } \\
\text { Rho }\end{array}$} & \multirow{2}{*}{ METs } & $\begin{array}{c}\text { IMT } \\
\text { Correlation } \\
\text { Coefficient }\end{array}$ & $\begin{array}{l}\text { Sig (2- } \\
\text { tailed) }\end{array}$ & $\begin{array}{c}\text { Correlation } \\
\text { Coefficient }\end{array}$ & $\begin{array}{c}\text { Sig (2- } \\
\text { tailed) }\end{array}$ \\
\cline { 3 - 6 } & & .235 & 0,100 & .092 & 0,523 \\
\hline
\end{tabular}


Berdasarkan tabel 9 menunjukan bahwa IMT dan gula darah tidak ada hubungan yang signifikan dengan pola aktifitas (sig $>0,05$ ).

\section{PEMBAHASAN}

Hasil penelitian ini menunjukan bahwa obese I (58\%) dan (42\%) obese II, Responden yang menunjukkan prediabetes $(28 \%)$ dan diabetes $(4 \%)$ dan yang memiliki nilai METs pada aktifitas fisik sedang (80\%). Obesitas dikaitkan dengan peningkatan risiko berbagai kondisi kesehatan termasuk diabetes, kanker, penyakit jantung, gangguan muskuloskeletal, dan kesehatan psikologis yang buruk (World Health Organization., 2018). Perawat adalah kelompok profesional terbesar dalam tenaga kesehatan, dan pekerjaan mereka dianggap menuntut fisik. Aktivitas fisik secara teratur membantu mencegah atau memperbaiki kondisi kardiometabolik. Sebuah studi di Skotlandia menemukan 69,1\% perawat Skotlandia kelebihan berat badan atau obesitas. Prevalensi kelebihan berat badan dan obesitas lebih tinggi pada perawat daripada profesional kesehatan lainnya (Kyle et al., 2016).

Perawat (sebagian besar adalah wanita) mewakili kelompok profesional terbesar dalam tenaga kesehatan dan banyak yang hadir dengan faktor risiko CVD. Beberapa penelitian telah mengukur aktivitas fisik dan perilaku menetap perawat dan menemukan tingkat aktivitas fisik yang rendah (yaitu sebagian besar tidak memenuhi pedoman aktivitas fisik) dan perilaku menetap tingkat tinggi (50-60\% dari hari). Perawat yang bekerja shift bergilir, shift 12 jam dan/atau bekerja penuh waktu atau paruh waktu (vs santai) mungkin berisiko lebih besar untuk tidak aktif secara fisik; Namun, kebalikannya telah diamati untuk perilaku menetap. Beberapa intervensi yang menargetkan tingkat aktivitas fisik perawat telah menunjukkan harapan, tetapi intervensi yang telah menggunakan monitor aktivitas dengan strategi perilaku; tidak ada penelitian, sampai saat ini, telah mengevaluasi dampak intervensi perilaku menetap pada perawat (Reed et al., 2018).

Hasil penelitian menunjukan bahwa ada hubungan yang signifikan antara usia dan pola aktivitas. Nilai correlation coefficient menunjukkan tanda positif yang berarti bahwa usia dan pola aktifitas memiliki hubungan yang searah dengan tingkat keeratan hubungan yang cukup. Selain itu, hasil penelitian menunjukkan bahwa ada hubungan yang signifikan antara marital dan pola aktivitas. Nilai correlation coefficient menunjukkan tanda positif yang berarti bahwa usiadan pola aktifitas memiliki hubungan yang searah dengan tingkat keeratan hubungan yang cukup. Seiring dengan bertambahnya usia, prevalensi obesitas sentral mengalami peningkatan. Peningkatan usia akan mengingkatkan kandungan lemak tubuh total, terutama distribusi lemak pusat. Prevalensi obesitas sentral meningkat sampai dengan usia 44 tahun dan menurun kembali pada usia 45-54 tahun. Prevalensi obesitas sentral ditemukan lebih tinggi pada sampel dengan usia lebih tua. Pada usia lebih tua terjadi penurunan massa otot dan perubahan beberapa jenis hormon yang memicu penumpukan lemak perut (Puspitasari, 2018).

Kegiatan aktivitas fisik yang dilakukan secara baik dan teratur berdampak terhadap komposisi tubuh yang lebih baik dan seimbang. Sehingga tubuh menjadi lebih sehat, bugarserta menjadi lebih produktif (Fitri et al., 2016). Rata-rata, perawat membakar 2,12 kkal per menit saat bekerja, setara dengan $1521 \mathrm{kkal} / 6364 \mathrm{~kJ}(\mathrm{SD}=403 \mathrm{kkal} / 1686 \mathrm{~kJ})$ per shift 12 jam. Pengeluaran energi selama 12 jam sangat bervariasi antara perawat (dari 812 $\mathrm{kkal} / 3397 \mathrm{~kJ}$ hingga $3005 \mathrm{kkal} / 12,573 \mathrm{~kJ}$ ) tetapi cukup pada $72 \%$ peserta (dengan asumsi tingkat pengeluaran energi istirahat minimal selama 12 jam tidak bekerja) untuk membakar asupan kalori harian 2000 kkal (Allan et al., 2019). Dalam penelitian tersebut, tiga perempat perawat menghabiskan lebih banyak energi pada hari kerja daripada yang dibutuhkan untuk 
mempertahankan berat badan yang sehat jika asupan makanan tidak melebihi tingkat yang direkomendasikan (Allan et al., 2019).

Kerja shift memainkan peran penting dalam kehidupan dan gaya hidup petugas kesehatan karena dapat memodifikasi dan menyebabkan timbulnya patologi dan dapat menyebabkan perubahan kesejahteraan fisik dan psikologis. Faktanya, kerja shift dapat mendesinkronisasi ritme kehidupan umum pekerja dan mengubah ritme fisiologis tubuh mereka.Pergeseran dan belokan berdampak kuat pada semua aspekkehidupan seorang pekerja, termasuk perubahan kebiasaan makan, aktivitas fisik, ritme sirkadian, serta berbagai jenis perilaku lainnya (Buchvold et al., 2018). Penelitian yang menyelidiki perubahan indeks massa tubuh (BMI) antara jadwal kerja yang berbeda dan jumlah rata-rata shift malam tahunan yang berbeda selama periode tindak lanjut empat tahun. Yang merupakan studi prospektif perawat Norwegia $(\mathrm{N}=2965)$ dengan jadwal kerja yang berbeda dilakukan: siang saja, dua shift rotasi (siang dan malam shift), rotasi tiga shift (siang, malam dan shift malam), malam saja, mereka yang berubah ke shift malam, dan mereka yang berubah dari jadwal yang mengandung shift malam (Buchvold et al., 2018).

Penelitian menunjukkan bahwa BMI meningkat secara signifikan lebih banyak di antara pekerja malam dibandingkan dengan pekerja siang.Tingkat aktivitas perawat yang relatif rendah di tempat kerja adalah salah satu penentu potensial kenaikan berat badan karena mereka menghabiskan sebagian besar jam bangun mereka di tempat kerja dan aktivitas waktu luang biasanya rendah. Penelitian ini bertujuan untuk mengukur pengeluaran energi perawat selama shift 12 jam standar untuk menentukan apakah tingkat aktivitas fisik mereka di tempat kerja cukup tinggi untuk membantu menjaga BB yang sehat.

Hasil penelitian menunjukkan bahwa tidak ada hubungan yang signifikan antara IMT dan Gula darah. Nilai correlation coefficient menunjukkan tanda negatif yang berarti bahwa IMT dan Gula darah memiliki hubungan yang berlawanan dengan tingkat keeratan hubungan yang sangat lemah. Menurut Suryanti (2020) Tidak ada hubungan antara indeks masa tubuh dengan kadar gula darah puasa pada penderita diabetes melitus tipe 2 . Berdasarkan penelitian terdapat hubungan antara usia dan status gizi dengan kadar gula darah maka disarankan bagi responden dengan IMT berlebih dapat mempertahankan berat badan ideal dan pada penderita DM tipe II pada usia lebih dari 40 tahun lebih menjaga pola hidup sehat yang dapat mencegah komplikasi diabetes karena kadar gula darah yang tinggi.

Pada penelitian Kahleova et al (2017) makan >3 kali/hari (snacking) dikaitkan dengan peningkatan relatif pada BMI ( $\mathrm{P}<0,001)$.Sejalan dengan itu, BMI subjek yang berpuasa semalaman lama $(\geq 18$ jam) menurun dibandingkan dengan mereka yang berpuasa semalaman sedang (12-17 jam) $(\mathrm{P}<0,001)$. Orang yang sarapan pagi $(-0,029$; CI 95\%: 0,047, -0,012; $\mathrm{P}<0,001)$ mengalami penurunan IMT dibandingkan yang tidak sarapan. Dibandingkan dengan subjek yang makan paling banyak saat makan malam, mereka yang makan sarapan sebagai porsi makan terbesar mengalami penurunan IMT yang signifikan (0,038; 95\% CI: -0,048, -0,028), dan mereka yang makan siang besar mengalami penurunan IMT yang lebih kecil. Orang dewasa yang relatif sehat, makan lebih jarang, tidak ngemil, sarapan, dan makan paling banyak di pagi hari mungkin merupakan metode yang efektif untuk mencegah kenaikan berat badan jangka panjang.

Perawat yang bekerja shift menunjukkan durasi puasa yang lebih pendek, variabilitas asupan energi sehari-hari yang lebih besar dan skor gangguan mood total yang lebih tinggi bila dibandingkan dengan rekan mereka yang tidak bekerja shift (semua $p<0,05$ ). Hasil penelitian ini menunjukkan bahwa mengatasi perilaku diet dapat meningkatkan kesehatan kardiometabolik dan psikologis perawat wanita. Perawat yang bekerja shift mungkin memerlukan program diet yang lebih spesifik untuk meningkatkan kesehatan psikologis 
mereka (Terada et al., 2019). Menurut penelitian Astiti \& Dwipayana (2018) menunjukkan tidak ada hubungan yang signifikan antara indeks massa tubuh dengan kadar glukosa darah puasa. Menurut Nababan (2020) penelitian menunjukkan tidak ada pengaruh antara indeks massa tubuh dengan kadar gula darah dengan p value 0,338>0,05 serta Ada pengaruh pola makan, aktivitas fisik dan Riwayat keturunan terhadap kadar gula darah.

National Institute for Health and Care Excellence (NICE) tentang pencegahan obesitas. Pedoman ini merekomendasikan bahwa tempat kerja mendukung tindakan untuk meningkatkan penyediaan makanan dan minuman di tempat kerja dan menawarkan program pendidikan dan promosi yang disesuaikan, seperti intervensi perilaku atau perubahan lingkungan. Temuan ini jelas menunjukkan kebutuhan untuk memotivasi perawat untuk mencapai aktivitas fisik secara teratur selama waktu luang mereka. NavajasRomero's et al., (2020) dalam perkiraan dasar dari penelitian variabel pusat, sampel umum profesional keperawatan tampaknya memiliki beberapa masalah dalam menyeimbangkan waktu pribadi dan pekerjaan mereka.

\section{SIMPULAN}

Perawat sebagai salah satu sumber daya yang berperan penting dalam pelayanan kesehatan dan memiliki peran yang esensial, pertama yaitu untuk melakukan promosi kesehatan dan pencegahan primer.

\section{SARAN}

Memberikan motivasi kepada perawat untuk mencapai dan mempertahankan berat badan yang sehat dengan menyediakan program manajemen berat badan di tempat kerja, pemeriksaan kesehatan khususnyamemastikan bahwa mereka menangani berat badan, diet dan aktivitas, dan memberikan dukungan berkelanjutan untuk menjaga kepatuhan.

\section{DAFTAR PUSTAKA}

Allan, J., Sadko, K., Bell, C., \& Johnston, D. (2019). How Many Calories do Nurses Burn at Work? A Real-Time Study of Nurses' Energy Expenditure. Journal of research in nursing : JRN, 24(7), 488-497. https://doi.org/10.1177/1744987119837586

Astiti, A. P., \& Dwipayana, M. P. (2018). Hubungan Indeks Massa Tubuh (IMT) dengan Kadar Gula Darah Puasa pada Siswa Sekolah Menengah Atas (SMA) Negeri di Wilayah Denpasar Utara. E-Jurnal Medika Udayana,7(3), 95-98. https://ojs.unud.ac.id/index.php/eum/article/view/38048/23079

Buchvold, H. V., Pallesen, S., Waage, S., \& Bjorvatn, B. (2018). Shift Work Schedule and Night Work Load: Effects on Body Mass Index - A Four-Year Longitudinal Study. Scandinavian Journal of Work, Environment and Health, 44(3). https://doi.org/10.5271/sjweh.3702

Fitri, Y., Mulyani, N. S., Fitrianingsih, E., \& Suryana, S. (2016). Pengaruh Pemberian Aktifitas Fisik (Aerobic Exercise) terhadap Tekanan Darah, IMT dan RLPP pada Wanita Obesitas. AcTion: Aceh Nutrition Journal, 1(2), 105. https://doi.org/10.30867/action.v1i2.19

Health and Safety Executive. (2017). LFS - Labour Force Survey - Self-Reported WorkRelated Ill Health and Workplace Injuries: Index of LFS Tables. https://www.hse.gov.uk/statistics/lfs/index.htm

Kahleova, H., Lloren, J. I., Mashchak, A., Hill, M., \& Fraser, G. E. (2017). Meal Frequency and Timing are Associated with Changes in Body Mass Index in Adventist Health Study 2. Journal of Nutrition, 147(9), 1-7. https://doi.org/10.3945/jn.116.244749 
Kumar, A, S., Maiya, A. G., Shastry, B. A., Vaishali, K., Hazari, A., \& Jadhav, R. (2018). Effectiveness Of Structured Exercise Program On Insulin Resistance In Type 2 Diabetes Mellitus - A Pilot Study. Indian Journal of Public Health Research and Development, 9(11), 88-91. https://doi.org/10.5958/0976-5506.2018.01430.4

Kyle, R. G., Neall, R. A., \& Atherton, I. M. (2016). Prevalence of Overweight and Obesity among Nurses in Scotland: A Cross-Sectional Study Using the Scottish Health Survey. International Journal of Nursing Studies, 53. https://doi.org/10.1016/j.ijnurstu.2015.10.015

Kyle, R. G., Wills, J., Mahoney, C., Hoyle, L., Kelly, M., \& Atherton, I. M. (2017). Obesity Prevalence among Healthcare Professionals in England: A cross-Sectional Study Using the Health Survey for England. In BMJ Open, 7(12). https://doi.org/10.1136/bmjopen-2017-018498

Nababan, A. S. V., Pinem, M. M., Mini, Y., \& Purba, T. H. (2020). Faktor yang Mempengaruhi Kadar Gula Darah Penderita Diabetes Mellitus (DM) Tipe 2 di RSUD Dr. Djasamen Saragih Pematangsiantar. Jurnal Dunia Gizi, 3(1). https://doi.org/10.33085/jdg.v3i1.4657

Navajas-Romero, V., Ariza-Montes, A., \& Hernández-Perlines, F. (2020). Analyzing the Job Demands-Control-Support Model in Work-Life Balance: A Study among Nurses in the European context. International Journal of Environmental Research and Public Health, 17(8). https://doi.org/10.3390/ijerph17082847

Puspitasari, N. (2018). Kejadian Obesitas Sentral pada Usia Dewasa. HIGEIA (Journal of Public Health Research and Development), 2(2), 249-259. https://doi.org/10.15294/higeia.v2i2.21112

Reed, J. L., Prince, S. A., Pipe, A. L., Attallah, S., Adamo, K. B., Tulloch, H. E., Manuel, D., Mullen, K. A., Fodor, J. G., \& Reid, R. D. (2018). Influence of the Workplace on Physical Activity and Cardiometabolic Health: Results of the Multi-Centre CrossSectional Champlain Nurses' study. International Journal of Nursing Studies, 81. https://doi.org/10.1016/j.ijnurstu.2018.02.001

Saulle, R., Bernardi, M., Chiarini, M., Backhaus, I., \& La-Torre, G. (2018). Shift Work, Overweight and Obesity in Health Professionals: A Systematic Review and MetaAnalysis. In Clinica Terapeutica, 169(4), e189-e197. https://doi.org/10.7417/CT.2018.2077

Suryanti, S. D., Raras, A. T., Dini, C. Y. \& Ciptaningsih, A. H. (2020). Hubungan Indeks Massa Tubuh dengan Kadar Gula Darah Puasa pada Pasien Diabetes Melitus Tipe 2. Poltekita : Jurnal Ilmu Kesehatan, 13(2), 86-90. https://doi.org/10.33860/jik.v13i2.46

Terada, T., Mistura, M., Tulloch, H., Pipe, A., \& Reed, J. (2019). Dietary Behaviour is Associated with Cardiometabolic and Psychological Risk Indicators in Female Hospital Nurses-A Post-Hoc, Cross-Sectional Study. Nutrients, 11(9). https://doi.org/10.3390/nu11092054

Wondmkun, Y. T. (2020). Obesity, Insulin Resistance, and Type 2 Diabetes: Associations and Therapeutic Implications. In Diabetes, Metabolic Syndrome and Obesity: Targets and Therapy (13), 3611-3616. https://doi.org/10.2147/DMSO.S275898

World Health Organization. (2018). Noncommunicable Disease Country Profiles 2018. World Health Organization. https://www.who.int/publications/i/item/ncd-countryprofiles-2018

World Health Organization. (2021). Obesity and Overweight. World Health Organization. https://www.who.int/news-room/fact-sheets/detail/obesity-and-overweight 